\title{
CANTIGA AO DESAFIO E ESTETIZAÇÃO DA FALA: NATUREZA, MODALIDADES, FUNÇÕES
}

\author{
Carlos Nogueira
}

RESUMO: In this article we offer a theory for the Portuguese "cantigas ao desafio" ("contest songs", poetic dueling). We shall approach them on the individual level, insofar as they are a personal creative act, and on a community level, envisaging them as a sociocultural phenomenon. Its necessary and interdisciplinary and multifaced approach arises from a poetico-musical specificity that doesn't become exhausted in musical and techno-literary components alone. It is a playful and creative game with a lot of anthropological and sociological ingredients, it is poetry in action. The contest becomes a dialogical macro-poem made out of two individual oral poems, intermingled in an alternance of forces, of variable tensions and distensions. The textual dimension is the more visible materiality of an organic process obeying to laws of improvisation in which linguistical-literary elements take part (ars poetica, grammar, rethoric, stylistics, themes, etc.). But it also obeys to extratextual factors with which the contesters interact very closely (the audience and the technological apparatus involved in some performances for mediatic purposes).

PALAVRAS-CHAVE: poesia, cantigas ao desafio, Portugal.

A complexidade e a diversidade das relações entre tradição e criação, voz e escritura encontramse exemplarmente actualizadas no conjunto poético cantado, recitado, improvisado, a que em Portugal se dá sobretudo a designação de cantiga ou cantar ao desafio, desafio, cantiga ou cantar à desgarrada, desgarrada, despique ou cante a despique. Nesses contextos de competição poética ritualizada de viva voz, antes de mais de natureza lúdica ou evasiva, mas também pragmática e psicanalítica ${ }^{1}$, cada cantador aspira ser declarado vencedor, após conseguir o agrado e os aplausos do público. Espaços e situações de interacção como os largos das aldeias, as feiras, as tabernas, os cafés ${ }^{2}$, as festas e as romarias são os mais apropriados para a manifestação dessas contendas, acesos espectáculos ao vivo, com muito de demanda de afirmação social, capazes de atrair a atenção apaixonada de inúmeros assistentes.

Pierre Sanchis (1992, p. 162) nota que, com diferentes exigências formais de acordo com a região, "o tema tradicional deste duelo de ciência e de poesia era outrora a história bíblica". A partir desse núcleo, em que os participantes demonstravam a sua competência exegética e histórica, assente nos conhecimentos adquiridos no antigo Ensino Primário, passava-se quase sempre para outros temas, que diríamos conformarem hoje os pontos cardinais dos bons cantadores, daqueles que são exímios na mudança de assunto, estratégia com que conquistam ainda mais vantagem sobre o adversário já em posição desfavorável ou intentam recuperar algum terreno perdido para o oponente: a vida pessoal dos antagonistas, principalmente no que se relaciona com a prestação sexual de cada um, em especial quando medem ou articulam forças um elemento, que é simultaneamente representante, do sexo masculino e outro do sexo feminino, a História de Portugal, os astros, o bem e o mal, a morte e a vida, o amor e o desamor, a riqueza e a pobreza, as profissões e os ofícios, a fé e a caridade, a cidade e o campo, a

Professor e pesquisador vinculado ao Centro de Tradições Populares Portuguesas "Prof. Manuel Viegas Guerreiro" - Universidade de Lisboa.

${ }^{1}$ Sobre as funções da poesia oral, cf. o nosso artigo "Funções da poesia oral" (1999).

${ }^{2}$ Num artigo exemplar com o título "Da taberna ao café: a casa dos homens", Miguel Vale de Almeida reflecte sobre as interacções geradas nestes espaços, suas funções, continuidades e descontinuidades, em correlação com o tema da masculinidade. 
biografia do cantador (ou da cantadeira) e o desafio, o pai e o filho, o empregado e o patrão, o homem e a mulher. Esta última dicotomia constitui um operativo ensaio e um reflexo aberto do poder dos homens e do poder das mulheres na sociedade portuguesa (e Ocidental), poder de tipo económico e social mas também sexual ("Tu não me cantes de galo/porque o galo sou eu;/mulher que cante de galo/não entra em poleiro meu"3), campo em que mais facilmente a mulher consegue perturbar a contumaz dominação masculina ("Tu não és homem normal,/ouve lá, ó Soalheira;/se eu fosse prà cama contigo,/podes crer, ficavas mal.//Não tens jeito nem feitio,/Ó Domingos, prò amor;/a única coisa que tens/é jeito pra cantador").

Embora decerto com imbatível tendência para o desaparecimento, ainda há encontros em que avulta a importância da escritura, quer dizer, dos ensinamentos livrescos passíveis de enquadramento nos desafios. Num interessante depoimento recolhido por Ana Paula Guimarães (2000, p. 247), um cantador afirma que "as cantigas valem pelo escrito", para mais à frente explicar que "cantar escrito é cantar sobre a História de Portugal, as vidas de santos, lendas como a Maria da Fonte, sobre a Terra, sobre o Mar, sobre a Lua...". A definição temática compete aos cantadores, antes do desafio ou, mais correntemente, logo no início da arte dialogal que esses obreiros da fala se propõem erigir, ainda que por vezes os temas sejam impostos pela comissão de festas e anunciados apenas com os intervenientes já em palco, depois de aberto um envelope. "Cantar por obra", "cantar com fundamento" ou, no Alentejo, "cantar por afundamento" são apenas algumas das denominações atribuídas a essa modalidade de desafio que se constrói a partir de um único tema predefinido. Mas há também As velhas da ilha Terceira, cujo travejamento consiste na ridicularização (mesmo se com muito de afeição e compreensão) de velhos e de velhas, particularmente os que casam, herdeiros de uma antiga tradição de velhas personagens presas à volúpia imediata, aos amores serôdios, ao culto do dinheiro e da aparência, marcadas a cada passo, como o velho peralta dos entremezes setecentistas, pelo burlesco cómico ou tragicómico ${ }^{4}$. Apesar de alguns estudiosos considerarem que As velhas não configuram propriamente um canto ao desafio, não há dúvida de que a situação risível desenhada por cada cantador estreita uma resposta e, mais do que isso, uma réplica que se pretende mais arrojada e original do que a do interlocutor, a quem são igualmente endereçados motejos personalizados. Também a formalização, a décima, desdobrada numa sextilha e numa quadra, com rima final entre o terceiro e o sexto versos, é constante e exclusiva dos Açores. A outra grande tipologia da cantiga ao desafio admite desvios mais ou menos constantes de assunto.

Alberto Pimentel (1989, p. 127) define imprópria e parcelarmente a cantiga ao desafio, nos mecanismos textuais que a caracterizam e nos intervenientes envolvidos. Sem chegar a dizer o que entende por improvisação, escreve: "Um dos piques que mais relevo dão aos serões é o cantar ao desafio, um duello de improvisos entre uma cachopa e um moço, que teem bossa de repentistas"s. Mais à frente, cedendo a um explícito impressionismo sem convincente espessura analítica, discorre sobre questões formais e de conteúdo, de novo num tom amador muito pouco exaustivo e incorrecto. Desconhece regras tão elementares como a do isossilabismo e a da estrutura dicotómica da quadra heptassilábica de pé quebrado (conhecimento que deveria passar, pelo menos, por uma apreensão intuitiva), a forma preferida do desafio português (embora sejam também frequentes outras arquitecturas, em especial a quintilha, a sextilha e a oitava) $)^{6}$ : As trovas revelam ordinariamente espontaneidade de improvisação, mas o verso raras vezes deixa de ser defeituoso. E de quando em quando há quebra de sentido, desconnexão de pensamento. Todavia o auditorio, tão ignorante como os cantadores, attende unicamente á promptidão da réplica" (PIMENTEL, 1989, p. 129).

No Brasil, a designação genérica cantoria recobre o conjunto da poesia oral cantada e improvisada segundo modalidades e regras poéticas muito precisas, com uma forte participação da performance oral - a interpretação/actualização de um texto perante um público -, que condiciona em larga medida a expressão, por força de uma troca dinâmica entre os dois cantadores e o seu público. Para se distinguir sem equívocos da peleja de cordel, que conforma uma representação por escrito de cantorias do passado, conservadas durante muito tempo nas memórias exercitadas dos cantadores estetas da palavra, denomina-se cantoria de repente (de improvisação), no Nordeste, com cerca de sessenta

\footnotetext{
${ }^{3}$ Os textos citados sem indicação de fonte, ouvidos a cantadores do Minho, foram recolhidos por nós nos Açores, na Ilha Terceira, entre 11 e 15 de Agosto de 2002, durante o II Encontro de Cantigas ao Desafio na Lusofonia, no qual participámos como conferencista.

${ }^{4}$ Cf., entre muitos outros, Francisco Sabino dos Santos, Entremez intitulado O Velho Peralta, de 1776.

${ }_{5}^{5}$ As Alegres Canções do Norte, edição fac-similada, 1989 (1 $1^{\mathrm{a}} \mathrm{ed}$. em 1905).

${ }^{6}$ Antes de se institucionalizar o recurso a agrupamentos de cinco ou mais versos, mais consentâneos com a naturalidade de um discurso oral sem restrições que pretende tornar as ideias e as emoções visíveis e audíveis, os repentistas brasileiros também estruturavam as suas produções em quadras. Coutinho Filho (1972, p. 48) nota que, "até 1870, pouco mais ou menos, quando Romano da Mãe d'Água e Inácio da Catingueira viviam sua época de ouro nos tronos da poesia sertaneja, a quadra turbilhonava na arena dos desafios memoráveis, nas pelejas ainda hoje lembradas pelo povo".
} 
modalidades; jogar versos, no Norte de Minas, com cerca de quinze modalidades; trova ou trovar, no Rio Grande do Sul, com cerca de dez modalidades; cururu, em São Paulo, com cerca de dez modalidades; tirar versos, no Centro-Oeste, com cerca de quatro modalidades; e partido alto, no Rio de Janeiro, com cerca de três modalidades. Na maior parte das ocorrências, a peleja implica uma reescrita subsequente ou uma construção ao jeito da cantoria, da autoria de um cordelista (poeta que escreve histórias rimadas e metrificadas, mas não canta de improviso) ou de um repentista ${ }^{7}$ que seja simultaneamente cordelista.

Mário de Andrade chamava desafio a qualquer manifestação poética oral improvisada, integrada numa cantoria ou como parte constitutiva de uma dança dramática ou de outra manifestação popular (designação que aliás ainda hoje é comum em certas áreas do Brasil). A terminologia - peleja, desafio remete de imediato para a ideia de combate, de violência, "omniprésente dans les joutes chantées traditionnelles, rivalité qui tend à s'stténuer, sinon à disparaître, dans les actuelles sessions de cantoria où les chanteurs se présentent plus en partenaires qu'en adversaires" (SANTOS, 1997, p. 29). No poema "Cantadores do nordeste", Manuel Bandeira (1958, p. 72) explora a técnica da literatura popular em verso, nomeadamente o ritmo próprio da cantoria e da correspondente poesia de cordel, actualizando assim os seus propósitos programáticos de realização de "Todos os ritmos sobretudo os inumeráveis":

Anteontem, minha gente,

fui juiz numa função

de violeiros do Nordeste.

Cantando em competição,

vi cantar Dimas Batista

e Octacílio, seu irmão.

Ouvi um tal de Ferreira,

ouvi um tal de João.

Um, a quem faltava um braço,

tocava cuma só mão;

mas como ele mesmo disse,

cantando com perfeição,

para cantar afinado,

para cantar com paixão,

a força não está no braço:

ela está no coração. (BANDEIRA, 1990, p. 341-342)

Vários folcloristas advogam para o desafio origens gregas, apoiando-se no funcionamento dos cantos amebeus ou alternados dos pastores. Mas a estabilização do modelo - poema dialógico que nasce do encontro, empírico ou fictivo, de pois poetas que esgrimem capacidades inventivas, criativas e emocionais, que se auto-elevam e reciprocamente se provocam, injuriam, quase sempre perante testemunhas - coube aos trovadores medievais, que muito apreciaram a "tenção", uma das formas mais conhecidas dos nossos Cancioneiros, através da qual trovadores e jograis melhor podiam evidenciar a sua mestria na arte de trovar. As inúmeras tenções de carácter satírico travadas entre jograis e trovadores parecem não deixar dúvidas de que a tenção figuraria uma espécie de prova, como sucede com o célebre ciclo em torno do jogral Lourenço. Exceptuando algumas tenções que constituem mais um diálogo irónico do que um confronto, visando geralmente uma terceira pessoa e não os próprios poetas, o cânone das tenções determina a ocorrência de duas posições antagónicas (típica dos cantares ao desafio). Na Arte Poética fragmentária com que o Cancioneiro da Biblioteca Nacional principia, preconiza-se, sobre esta maneira de trovar a dois, que um "diga aquelo que por ben tever na prima[eir]a cobra, e o outro rresponda-lhe na outra dizend[o] o contrayro". Outros investigadores preferem conectar a origem do desafio com a tradição repentista árabe, muito frequente em todo o Mediterrâneo (SOLER, 1978). Seja

\footnotetext{
${ }^{7} \mathrm{O}$ repentista recebe denominações diferentes em função dos instrumentos de que faz, ou não, uso, de requisitos de natureza formal e da não utilização do canto: poeta cantador, quando improvisa ao som da viola (com rima correcta ou perfeita); coquista ou embolador, se improvisa ao som do pandeiro ou da ganza (atende sobretudo à rima do som); aboiador, quando, sem se munir de qualquer instrumento, improvisa ao som do aboio, fazendo aboios com as vogais nos intervalos dos versos e usando as duas formas de rima; e glosador, quando improvisa sem cantar, utilizando também os dois tipos de rima. Comuns às várias especificidades do repentismo são as exigências técnico-estilísticas e a observância da coerência do conteúdo, numa tripartição a que os repentistas não podem deixar de obedecer com rigor (a métrica, a rima e a oração). Téo Azevedo, um dos mais famosos repentistas brasileiros da actualidade, caracterizou-nos assim aquele último parâmetro, numa conversa que desenvolvemos com ele durante o congresso Literatura de Cordel - A Imprensa do Povo, em Santos (São Paulo, maio de 2002): "Oração é o mesmo que enredo. Durante uma cantoria, se um dos cantadores falar em elefante, o outro não poderá falar em caminhão, a não ser que ele diga nos seus versos que o caminhão serve para carregar o elefante".

${ }^{8}$ No texto bandeiriano, a osmose erudito/folclórico processa-se sem complexos, gerando uma nova dicção estética que surgirá nos modernistas e se manterá no Bandeira (1958, p. 72) autor de poemas como "O anel de vidro", que assume como intertexto uma afamada quadra tradicional portuguesa (quadra solta, por vezes absorvida, nas tradições portuguesa e brasileira, em modas e em cantiga infantis de roda): "Aquele pequenino anel que tu me deste, $/$ Ai de mim - era vidro e logo se quebrou.../Assim também o eterno amor que me prometeste,/-Eterno! Era bem pouco e cedo se acabou."
} 
qual for a teoria mais correcta, e independentemente das variantes nacionais, é certo que se trata de uma prática artística com raízes longínquas e de muitos povos, como o inga fuka do Índico Oriental, o pantun malaio, o haikai japonês ou as várias modalidades próprias dos países sul-americanos. Na payada argentina, por exemplo, é comum focalizar-se muito mais a desenvoltura dos conhecimentos patenteados do que a força da improvisação. Esta aptidão para cantar ciência também existe no Brasil, embora muito menos explorada e apreciada. O cantador mais aplaudido não é necessariamente o mais culto ou sapiente, mas aquele que improvisa de modo ágil, vivo, e respeita com fidelidade os modos e os géneros consagrados pela tradição9. Raúl Eduardo González - jovem estudioso mexicano com várias obras publicadas sobre literatura oral, popular, tradicional, e discípulo, por assim dizer, da escola de Margit Frenk e Araceli Campos Moreno - facultou-nos, amavelmente, esta actualizada informação por escrito (depois de um colóquio muito produtivo em Espanha, onde pudemos trocar fecundas impressões):

Los desafíos poéticos, en México, son llamados, en general, "controvérsias"; en la región de la Sierra Gorda de Guanajuato, se les llama "topadas"; en ellas, los poetas se enfrentan durante toda la noche, acompañados de la música de violines, guitarra y vihuela, enfrentados en un baile popular. Ambos poetas (que junto con sus músicos se sientan en bancos de madera dispuestos muy alto sobre el suelo, digamos, a unos dos metros) cantan y recitan sus poemas (generalmente glosas) en los cuales hablan sobre diversos asuntos de interés comunitario. A cierta hora de la madrugada inician el ataque directo entre ellos; a eso se le llama "bravata" o "aporreón".

O sucesso do desafio na captação da atenção e emoções do auditório depende em grande parte da forma mais ou menos hábil como os cantadores exibem a sua flexibilidade mental e verbal, executantes que "nunca poderão reconfortar-se à sombra de um playback ou que cairão no descrédito se banalizarem a cantoria" ". Como nos descantes ${ }^{11}$, os desafios suscitam a manifestação dos improvisadores, cuja acção é vital para o enriquecimento da literatura de transmissão oral. Nos desafios improvisados, autênticos, a composição coincide com a performance, pelo que o executante é também compositor. Esclareça-se desde já que a improvisação - cujas importância e dificuldade residem na celeridade da resposta, na organização dos materiais e no ajustamento às condições e vicissitudes inesperadas - deve ser entendida numa perspectiva de liberdade condicionada, no sentido de que nunca é absoluta. Mesmo nos casos em que há coincidência entre criação e prolação/transmissão, a composição oral obedece a regras preestabelecidas, cujo peso varia de executante para executante. $\mathrm{O}$ improvisador deve organizar rapidamente os materiais preexistentes - culturais, temáticos, poéticos, retórico-estilísticos, musicais -, matizando-os com elementos novos, ou nunca ditos ou quase-já-ditos, processo de que resulta uma textualidade original. $\mathrm{O}$ paralelismo, enquanto reiteração, em estrofes sucessivas, de sentidos ou de construções sintácticas, ou enquanto simples repetição de versos, quase sempre os dois primeiros ou os dois últimos mas também um ou outro verso solto, de que provém a dilatação da estrofe como espaço de matéria significante, é o dispositivo técnico mais característico de uma arte verbal que estetiza a voz, os gestos, o corpo. Essa estruturação rítmica é muitas vezes apurada pela utilização do leixa-pren, que, não obstante as restrições discursivas que impõe, autoriza uma progressão ponderada do pensamento e do discurso dos cantadores, distendendo gradualmente estados emotivos, constrangimentos, incómodos, antipatias ou empatias; como é apurada por engenharias rímicas que passam, por exemplo, pela recuperação, no primeiro verso da resposta, da última rima final do adversário, o qual, se não prosseguir com o mesmo apuro técnico, é, pelo menos nesse plano, superado; ou pelo uso, na replicação, como terceiro e quarto verso, dos dois primeiros versos invertidos da quadra antecedente, prescrição a que sobrevém, para não se "pisar o ponto", o impedimento de repetir o vocábulo que rima; ou ainda, entre outras, pelas particularidades técnicas de, ao longo da prestação, não se repetir qualquer uma das palavras utilizadas no fim do segundo verso, a par da obrigatoriedade de, quase sempre, não se "fugir ao ponto" (a terminação predefinida do segundo verso), características do cantar que A. Machado Guerreiro (1981, p. 61) designa de despique, exclusivo, segundo o autor, do Baixo Alentejo, da "Meia-Serra" e da "Serra do Algarve", "tanto do lado que desce para o Baixo Algarve como do que desce para o Alentejo". Mesmo se a pormenorização contextual e técnicoestilística apresentada por este estudioso é, para a modalidade em estudo, formulada de modo convincente, preferimos continuar a aceitar também para o termo "despique" um significado mais genérico, dado o seu emprego um pouco por todo o país; mas com a reserva de que, na zona especificada,

\footnotetext{
${ }^{9}$ Para uma descrição das linhas essenciais desta "poésie de l'instant", muito mais diversificada e codificada do que a tradição congénere portuguesa, cf. Idelette Muzart-Fonseca dos Santos (1997, p. 27-41) e Julie Cavignac (1997, p. 77-102).

${ }^{10}$ Arnaldo Saraiva, "Cantigas ao desafio", in Jornal de Notícias, 26/10/85. Cf. também, do mesmo autor, "Assim se fazem as cousas (populares) ou os grandes desafios de um pequeno desafio" (SARAIVA, 1992, p. 35-39).

11 "No nosso povo ha diversos improvisadores, que apparecem não só nos desafios como nos descantes. [...] As cantigas nos descantes são cantadas ao som de musica. Um descante, na Beira-Alta, é um ajuntamento de povo que geralmente dança a chula ao som da rabeca, da viola, dos ferrinhos e do bombo" (VASCONCELOS, 1890, p. 20-21).
} 
a denominação possa ter um alcance mais circunscrito a uma modalidade de desafio ${ }^{12}$ (tal como sucede, por exemplo, com o "baldão"), embora o autor não nos diga se tal designação é empregue por especialistas ou pelos poetas e utentes, ou por uns e outros. De facto, nem o argumento de que a estrofe, no "despique", é pessoal e por assim dizer intransmissível basta para validar a denominação (em Baião, é célebre um cantador que responde sempre em cinco versos, mesmo que o outro autor-intérprete utilize a quadra, residindo nessa particularidade técnica, com incidências desde logo ao nível dos códigos fónicorítmico e léxico-gramatical, uma parte substancial do seu orgulho de poeta-cantador competente e singular, inimitável; e nem por isso há uma designação distinta para esse caso, que, decerto, não é único no concelho nem no país, neste ou noutros moldes): há, para qualquer tipo de desafio, poetas-cantadores que não usam senão estrofes improvisadas ou criadas por si próprios (apesar de, obviamente, nenhum poeta rejeitar fórmulas mínimas, quer dizer, versos ou fracções versíficas, expressões idiomáticas, provérbios, etc., pertencentes à comunidade); ou, mais frequentemente, pela aplicação de rimas "fracas" ou "fáceis" (as terminações -ão e -ar e são as mais comuns) e rimas "fortes" ou "difíceis" (como em -er).

Compor, cantar e actuar são assim facetas do mesmo acto, no qual a música vocal, acompanhada ou não por instrumentos que apoiam o canto (a viola, a guitarra, o cavaquinho e, mais modernamente, o acordeão), se submete até certo ponto ao texto linguístico, servindo-lhe de suporte valorativo, o que não anula a importância da sedução estética que dela emana. O desafio é um jogo dialogado, mais cantado do que falado ou recitado, residindo aliás no canto ${ }^{13}$ - e não é por acaso que Portugal se afirma como "país das cantigas", nas palavras do memorável e inesquecível trovador moderno José Afonso - e na música instrumental a parte mais sensorial, íntima e ininteligível da sua vibração persuasiva: uma aptidão encantatória e irruptiva dos sentidos dos intérpretes e dos assistentes, produtora de coerência social por via da regulação poético-verbal de tensões e de sofrimentos reprimidos e do estabelecimento de vectores de sociabilidade. As formas poéticas convivem geralmente com formas musicais já antigas, tradicionais, construtoras, ambas, de um produto poético-musical sempre renovado e irrepetível. O vira, o malhão e a cana verde são as principais estruturas musicais do desafio, que, dependendo dos tocadores, ora surge acompanhado por uma sequência musical que se repete ciclicamente, ora por um tom rítmico que acompanha as diferentes modulações prosódicas da voz dos cantadores.

A dimensão estética dos desafios, ordinariamente ignorada por um certo senso comum de elite e pelos discursos histórico-literários ou críticos, aliás escassos no nosso país, apresenta a particularidade de, em muitas ocorrências, jogar com componentes que convocam análises de natureza por assim dizer racionais. É que, mesmo admitindo a relativa frequência de momentos líricos canónicos, não restam dúvidas de que os apontamentos considerados pela ideologia oficial prosaicos, grosseiros ou obscenos representam o capital mais proeminente dessa poesia, sem que isso obste à emergência de indefiníveis sentimentos estéticos nos executantes e no auditório. Essa fruição depende, numa percentagem considerável, não só da arte poética que codifica o género, mas também da convocação de elementos de substância extralinguística e cinésica (altura, timbre e tom de voz, gestos, expressões do rosto, etc.).

A esse processo acresce o imperativo de uma escuta atenta, pelo que o bom desafio vale também por aquilo que compreende de paradigmático em termos de modelo de comunicação. Essa articulação não se verifica nos desafios preconcebidos, imaginados, preparados, que constituirão o maior número daqueles que se encontram registados em folhas volantes e folhetos de cordel. A presença de um folclorista num desafio, apto a proceder à gravação, só ocasionalmente se verifica, a não ser nos encontros combinados, embora, nessas circunstâncias, o desafio não possa ser considerado absolutamente autêntico. Ou melhor, para não entrarmos em purismos: trata-se de um tipo particular de desafio, cada vez mais enquadrado na sociedade tecnológica e ultramediatizada que é a nossa (referimo-nos, por exemplo, aos desafios organizados por académicos, dentro de conferências nacionais ou internacionais). Não é por isso de estranhar que muitos dos desafios com fixação tipográfica procedem inequivocamente apenas de um autor que fingiu o encontro dramático ${ }^{14}$. Arnaldo Saraiva fala na "ficção do desafio: um poeta tenta

\footnotetext{
${ }^{12}$ Machado Guerreiro (1981, p. 63) nota que “a estrutura é diferente não só das quadras de todos os cantares populares mas ainda de toda a poesia portuguesa que conhecemos. De facto, cremos que debalde se procurará na nossa poesia, desde a dos Cancioneiros até à actual, composições com a estrutura estrófica do cante a despique - $\mathrm{ABCA}+\mathrm{BA}$, em que o primeiro verso rima com o quarto, o segundo e o terceiro versos são brancos, o segundo se repete como quinto e o primeiro figura como sexto".

${ }^{13}$ Não isento de ambiguidades, o termo "canto" recobre uma forma muito particular de fonação e de entoação que tem suscitado interessantes debates sobre a "dificuldade de distinção entre falado e cantado", duas formas de produção vocal em torno das quais "se situam inúmeros fenómenos vocais tendendo, ora para a melodia falada, ora para a melodia recitada, ora para o Sprechgesang, ora ainda para a melodia cantada. Tanto assim que, ainda que não seja considerada propriamente 'música' por um determinado grupo cultural, 'toda a produção vocal, independentemente da definição falado/cantado, é considerada musical'” [segundo George List, na obra The Boundaries of Speech and Song, de 1963, citado por Charles L. Boilès, "Canto", in Enciclopédia Einaudi, n. 32, Lisboa, Imprensa Nacional - Casa da Moeda, 1987, p. 269] (GUIMARÃES, 2000, p. 225).

${ }^{14}$ Cf., por exemplo, Novas cantorias para serem cantadas ao desafio entre Manuel e Maria, de João Zero.
} 
transcrever o que ouviu num desafio autêntico, um poeta escreve o desafio atribuindo ao adversário, ou aos intervenientes, as palavras e versos que quer atribuir-lhes" ${ }^{15}$. Na cultura urbana, a sugestão do desafio liga-se indissoluvelmente ao $\operatorname{rap}^{16}$ e a outras canções dialogadas contemporâneas, quase sempre envolvendo uma voz masculina e outra feminina, de que o grupo irlandês The Pogues nos dá talvez dos registos mais perfeitos e sedutores.

Os desafios não surgem exclusivamente de um acordo pacífico entre os cantadores. Desenquadrados de um ambiente programado, podem ser motivados por questões pontuais relacionadas com o quotidiano e servir para comparar forças e resistências, procurando cobrir o vencedor de glória e o adversário de ridículo. Em tais casos, o que suscita o confronto não é propriamente a ideia de desafio enquanto jogo entre iguais; jogo através do qual se mede a criatividade e a integridade de cada um na resposta adequada à boa pergunta, num quadro de valores e actos axiológicos por todos assumido de um modo ou de outro. A quadra seguinte sobreviveu a um desafio que opôs dois laureados cantadores da Teixeira (concelho de Baião); um deles, por estar não só a ser vencido mas também humilhado, foi ajudado pelo irmão, que se apresentou desta forma:

Eu nunca cantei à festa,

Nem foi minha criação;

Canto agora aqui

Por ser por meu irmão.

Recorda-se, pois, o que tem significado num arquivo oral, cujos eventos, verbais ou não-verbais, apresentam uma escala de significado. O resultado é o enriquecimento da tradição, a partir da recordação e da transmissão dos fragmentos poemáticos de maior valor emotivo.

Nesses contextos de acção, portanto, a hostilidade aberta - se bem que em alguns contextos substituída por uma apurada cortesia que leva o cantador mais forte a auxiliar e a animar o mais fraco ${ }^{17}$ é uma marca por excelência dos textos de concretização pública aí concebidos. Maria Luísa Carneiro Pinto (1949, p. 152) relata-nos uma oposição entre dois indivíduos, motivada por questões amorosas: "Uma noite, um rapaz, que estava doente, suspeitou que tinha no baile preferido rival. Levantou-se [...] e foi da porta ver o que se passava, supondo que não seria descoberto. O outro, porém, lobrigou-o e não desprezou a ocasião de o vencer pelo ridículo". O embate, que poderia ter sido físico, traduziu-se numa construção verbal engenhosa, organizada em tercetos, estrutura relativamente rara, com obrigatoriedade de rima final entre os versos finais de cada estrofe, o que produz uma sextilha construída pelos dois contendores:

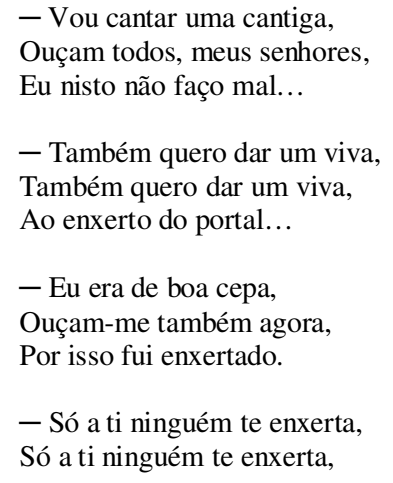

\footnotetext{
${ }_{16}^{15}$ Arnaldo Saraiva, "Cantigas ao desafio", in Jornal de Notícias, 26 out. 1985.

${ }^{16}$ Sobre essa actividade criadora de ressonância folclórica, cf. Richard Shusterman (1982), L'Art à l'État Vif - La Pensée Pragmatiste et l'Esthetique Populaire, e, sobretudo, José Augusto Mourão (1998, p. 259-269), "Poéticas da comunicação: literatura tradicional e rap". Eminem é, nesse aspecto, um ícone de grande parte daqueles que participam nas "batalhas", cujo apresentador instiga, com toques de humor, ironia e sátira, a audiência, que, ao som de hip-hop, dança e canta efusivamente, durante e sobretudo entre cada actuação (cada rapper dispõe, regra geral, de 45 segundos para se debater com um adversário). Como nos desafios de que aqui tratamos, é o público quem, através de uma ostensiva e variada semiótica do corpo, declara o vencedor, que deve escolher novo adversário, até se chegar à esperada final, em que cada intervenção é de 1 minuto e meio. Talvez mais do que no desafio português e respectivos congéneres internacionais, ocorre aqui uma evidente expurgação de energias disfóricas e uma consequente prevenção de violência física (mesmo se, por vezes, o efeito é precisamente contrário).

${ }^{17}$ Essas palavras de um executante ilustram bem os princípios ou o código deontológico dos cantadores: "A ideia é 'agradar' e 'tentar' enrolar o parceiro", "medir forças" mas "não com a força", com "a força do improviso". "Se o parceiro for mais fraco e não tiver pedalada (pode cantar mal mas canta o que sabe...), vou-lhe dando a mão, vou segurando esse adversário até aparecer um mais forte" (GUIMARÃES, 2000, p. 246). Alguns testemunhos mostram mesmo como o eufemismo (perifrástico, no caso aduzido a seguir), aplicado a conceitos e a termos relativamente inócuos, pode constituir um procedimento retórico-estilístico de base: "O que é preciso é não se ser 'directo, nem dizer palavras feias' (explicava-me Bernardino Carvalho), por exemplo, em vez de dizer 'mentiroso', dizer 'ele não fala verdade'” (GUIMARÃES, 2000, p. 247).
} 
Meu catrapeiro arejado...” (PINTO, 1942, p. 151-152)

A violência física latente dilui-se no acometimento verbal do desafio (e na gestualidade controlada que ele implica), em formas poéticas que agem como engrenagens de controlo da agressão. Carmelo Lisón (1974, p. 53-54) já frisou bem a relevância deste mecanismo para a "armonía comunal", a propósito das expressivamente designadas "disputas" galegas. O fim matricial comum será, ressalvando os casos em que o desafio, inversamente, acende momentos de concussão corporal, se não a plenitude de uma paz duradoura e sincera, pelo menos o esclarecimento recíproco, conducente a um exorcismo individual e colectivo.

$\mathrm{Na}$ dramatização codificada configurada pelo desafio, a adaptação do texto ao ouvinte faz-se durante a performance. Na execução do poema, diversas marcas linguísticas, paralinguísticas ou gestuais assinalam as interacções entre o emissor e a assistência, contribuindo para o arranjo dramático da performance, estabelecendo um ambiente de conivência entre as duas partes. A inclusão no desafio do nome de um ouvinte ou ouvintes particulares é um dispositivo retórico ao qual se recorre com frequência, como na cantiga que se segue, gravada num encontro de cantadores que organizámos em Baião:

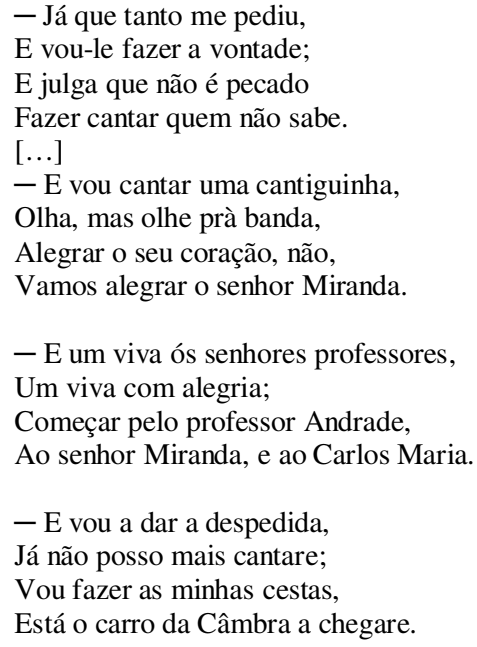

O poeta-intérprete altera o discurso, o tom, a entoação, o timbre de voz e os gestos, de acordo com a recepção que pressente ou percebe no auditório. A instabilidade da audiência requer um apurado grau de concentração por parte do cantador, para que possa actuar sem constrangimentos, sustentado por um complexo conjunto de sintonias. Testa-se até ao extremo a sua habilidade dramática e a sua capacidade inventiva para manter a audiência interessada. Os cantadores actuam até que, por cansaço, por motivos diversos de ordem pessoal ou influenciados pelo desassossego dos ouvintes, julguem oportuno terminar: "Mas esta é pra terminar/isto está a chegar ao fim;/por isso, termina pra ti/e, Joaquina, pra mim". Frequentemente, ao constatarem que a audiência não está receptiva (pode mostrar-se crítica, impaciente, intransigente), abreviam a disputa ou interrompem-na. O público avalia, selecciona e comenta as prestações dos disputantes, durante e após os diálogos cantados. Não é raro a fama de um cantador implicar a sua deslocação a outros lugares, o que acaba por enriquecer os esperados encontros públicos, devido sobretudo à motivação acrescida que recai sobre os cantadores locais.

Nas cantigas ao desafio, a audiência, claramente separada dos executantes, está presente para assistir à actuação, mas dela resultam por vezes novos participantes, entusiasmados com as prestações dos cantadores. Os assistentes apreciam os impulsos repentistas, a perspicácia verbal, o adestramento técnico, a força da réplica, as confidências e inconfidências, o inesperado, o segundo sentido, o chiste, a provocação e o humor picante, ingredientes impreteríveis nestes confrontos. No excerto que transcrevemos a seguir, a cantadeira empregou o termo "calcanhares" em vez de "saia", que previsivelmente rimaria com "Maia", no sentido de gorar as expectativas dos ouvintes, instaurando assim um efeito de surpresa, que contribui para o estabelecimento do cómico. Apoiada numa metáfora, que, com significado dúplice, parece a princípio óbvia, alargada, por outro lado, numa sugestiva imagem ("o bicho que mata os homens"), a referência sexual é activada para ser imediatamente obstruída ("Anda dubaixo dos calcanhares"):

- Já que tanto me pede,

Eu não sei qu'hei-de dizere,

Se le vou cantar das vermelhas,

O senhor manda-me prendere. 
- E sou do Porto, vou prò Porto,

Ai, sou da Maia, vou prà Maia.

E o bicho que mata os homens

Anda dubaixo dos calcanhares.

Noutras ocorrências, figuram quadros imagéticos que produzem efeitos cómicos a partir de uma poética do obsceno mais declarada, actuante apenas no âmbito das coordenadas culturais da própria comunidade. Fora dessas fronteiras, descontextualizados, sem a cumplicidade entre cantadores e ouvintes, segmentos como esses, prontos a desencadear o riso - importante acto de sociabilidade e de integridade individual pelo que tem de "movimento de relaxamento" (BERGSON, 1993, p. 132) -, podem ser sinónimo de mau gosto:

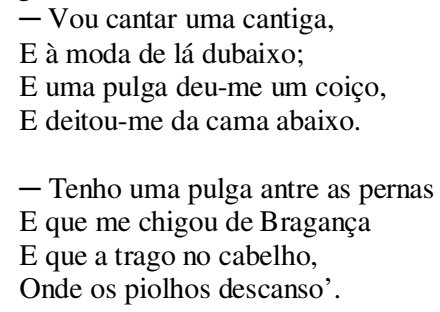

O palavrão, quer dizer, a linguagem livre, desabrida, por preconceitos e fundamentalismos de diversa ordem, gera normalmente obstáculos à recolha, divulgação e estudo do desafio. No texto que introduz os "Desafios" do seu Cancioneiro Popular de Mondim de Basto, por exemplo, Borges de Castro (1982, p. 85) confessa o seu repúdio pelo "obsceno e baixo humorismo", chegando mesmo a afirmar profundamente incomodado por esse tipo de textos - que "A sujeira desta espécie de desafios não merece papel e tinta, não tem aqui cabimento". Os próprios executantes, perante forasteiros pouco familiarizados com o ambiente do desafio, podem reprimir a inclusão do obsceno nos textos cantados ou recitados. Ora, a verdade é que o prestígio do cantador não pode dispensar a ousadia verbal, a resposta acintosa e pronta, o palavrão na sua dimensão mais insultuosa. O uso do calão, isto é, a linguagem caracterizada por termos obscenos ou, pelo menos, considerados grosseiros, só será por isso motivo de perplexidade para aqueles que ignoram a energia própria das palavras. Numa sugestiva crónica intitulada "O palavrão", Arnaldo Saraiva (1995, p. 131) comenta o uso dos palavrões em Portugal, afirmando, em tom de síntese: "Mas a força de um palavrão é um artifício social imposto pela hipocrisia e só quem se ofende com o uso do palavrão (se este não for um insulto pessoal) garante, como um primitivo, ou um insuspeitado primário, a sobrevivência do palavrão - do tabu". Na poesia oral como na literatura dita culta - desde a arte satírica trovadoresca a Gil Vicente, a Bocage e a João de Deus, a Alexandre O’Neill, a Alberto Pimenta e a Adília Lopes -, o trabalho literário vale-se com frequência da palavra viva, corrente, desbragada, como instrumento de expressão da mentalidade e da sensibilidade do grupo social.

Mas não se pense que o palavrão, no texto literário popular, da quadra oral e do desafio ao graffiti, serve apenas intuitos ofensivos ou depredativos. Pelo contrário, o seu maior valor reside muitas vezes no que encerra de catártico, de libertação de energias negativas, como fica claro também neste breve poema autobiográfico e sentencioso, que surpreendemos perpetuado numa mesa, na Escola Superior de Educação do Porto, em 2001:

A vida é filha da puta

A puta é filha da vida

Mais vale a vida de puta

Que a puta da minha vida.

Numa famosa e exemplar quadra da literatura de retrete, a mesma que os brasileiros denominam de literatura da latrina, latrinária ou frases da privada, vemos como a obscenidade pode pactuar com conceitos de índole elevada, solene, animada pelo disfemismo inesperado, estrategicamente colocado no final do poema e de verso. O aproveitamento de um defeito exclusivo do Homem - a vaidade -, tratado de diversas formas na literatura universal desde a Antiguidade Clássica (vanitas vanitatum), aparece neste texto suavizado por um humor saliente e fino, que advém da descrição concretizante de uma inevitabilidade fisiológica tão humana (e animal) quanto prosaica. A imagética difusa e supostamente associada a um referente nobre que serve de suporte à representação da retrete - um "lugar solitário" - e à sua função parte dos traços fundamentais desse espaço: a solidão e a intimidade que rodeia o acto de defecar, geralmente ignorado, encoberto ou apenas referido por eufemismos, porque conotado com o que o ser humano tem de mais degradante ou humilhante. Pela mestria da sua arte poética (forma estrófica, 
métrica, rima), pela sua retórica, pela sua estilística, é sem dúvida um poema que merece figurar como epígrafe ou representante do género (ou do local) numa qualquer colectânea desta literatura fedorenta ${ }^{18}$ :

Neste lugar solitário,

Onde a vaidade se acaba,

Todo o fraco faz força ${ }^{19}$,

Todo o forte se caga.

O desafio transcrito a seguir poderá funcionar como modelo do registo agressivo, chocarreiro, apesar de prescindir de vocábulos que, no uso comum, pontuam no topo da hierarquia ofensiva. Nele figuram grande parte dos instrumentos característicos da sátira declarada, como a insistência em defeitos físicos, as referências escatológicas e os traços zoomórficos, destinados a surpreender o adversário pelo ridículo caricatural que sobre ele recai. Todas as quadras obedecem à estrutura dicotómica, na sua modalidade mais comum: aquela em que os dísticos surgem formalmente independentes, como duas frases apostas, sem qualquer elo semântico a uni-los. A primeira parte, que comporta por vezes um verso inofensivo, quase infantil - como "Desafio da chaminé" ou "No pauzinho da canela" -, vale fundamentalmente como pretexto para a rima, mas, ao desviar ou atenuar por momentos a agressividade léxico-semântica, acaba por amplificar o arrebatamento do insulto expresso no quarto verso. Os versos migratórios "- Desafio, desafio" e "Nunca me desafiei" unificam esta forma poética e inscrevem-na na tradição oral comunitária, sublinhando quer o seu tom de praxis combativa, quer a vertigem provocada pelo peso bélico das palavras ${ }^{20}$ :

-Ó desafio, desafio,

Desafio pela navalha;

Nunca me desafiei ${ }^{21}$

Com semelhante canalha.

- Desafio, desafio,

Desafio pelo repolho;

Nunca me desafiei

Com semelhante mirolho.

- Cala-te lá, boca aberta, Espantilho do meu nabal;

Por um lado, já estás podre,

Do outro já cheiras mal.

- Ó desafio, desafio,

Desafio da chaminé;

Nunca me desafiei

Com semelhante chimpanzé.

- Ó desafio, desafio,

No pauzinho da canela;

Nunca me desafiei

Com semelhante cadela.

- Ó desafio, desafio,

Desafio pelo chão;

Nunca me desafiei

Com semelhante focinho de cão.

- Ó desafio, desafio,

Desafio do mantelo;

Mas tu, ó compadre,

Tens focinho de vitelo.

\footnotetext{
${ }^{18}$ Cf. Saraiva (1980, p. 102-107).

${ }^{19}$ Var.: Todo o cobarde faz força.

${ }^{20}$ No livro Las Malas Palabras, o psicanalista argentino Ariel C. Arango correlaciona, de forma sólida e convincente, a utilização dos palavrões com o equilíbrio físico e espiritual (apud SARAIVA, 1995, p. 130). Já Freud, de resto, afirmava que a libido exerce a sua acção através de construções linguísticas, até se operar a sua diluição no desejo. Se a língua é objecto de amor e de prazer, se as palavras pesam como pedras ou têm a leveza do inefável, não surpreende que o ser humano institua com a linguagem um relacionamento de orientação erótica. Cf., por exemplo, Yaguello (1990).

${ }^{21}$ Var.: Eu nunca desafiei.
} 
- Ó desafio, desafio,

Desafio da panela;

Mas tu, ó minha comadre,

Tens focinho de vitela.

- E agora, para acabar,

Paleio não vou dar mais;

Aquele que continuar a falar,

É o mais burro dos animais.

O final abrupto, superlativo, com diferentes graus de originalidade e contundência conforme a perícia individual, é uma fase decisiva do protocolo performativo do desafio, uma vez que pode atribuir a vitória a um dos participantes. Ao remate anterior - que consideramos muito interessante pela forma decidida como o cantador introduz a conclusão, caracteriza a actuação do adversário e inviabiliza a sua resposta - juntamos este, admirável pela apoteose delicada mas fingida, sugestivamente irónica, da figura feminina, no primeiro dístico e primeiro verso do segundo, e pela desconstrução desse cenário através do prosaísmo emergente do último verso (estrofe cujo conteúdo, mesmo se lhe corresponde uma estrutura de superfície bem menos agressiva ou crua, não é muito comum nos desafios de cordel, devido à acção da censura, que pode começar no próprio autor, seja pelo que nele é já comedimento ou inibição, porventura só na escrita, se ele é também cantador, seja pela projecção que ele faz dos gostos e da sensibilidade do editor e dos leitores; como não é propriamente abundante nos desafios publicados em cancioneiros e monografias etnográficas por estudiosos ou curiosos da literatura oral):

- Eu gosto de ti, Rosinha,

E quero-te pela vida!

O encanto dos meus olhos

É ao fundo da barriga. (VASCONCELOS, 1975, p. 186)

A recepção pode, por outro lado, resultar numa interiorização profunda conducente a uma nova performance, mais ou menos próxima do seu modelo. A produção das cantigas ao desafio depende do equilíbrio entre um património de estruturas formulísticas consagradas pela tradição e um conjunto de técnicas e de capacidades que se conciliam com a inventividade do poeta ${ }^{22}$. Sabe-se, com efeito, que muitos dos versos e estrofes utilizados pertencem à tradição oral da comunidade, como acontece com a segunda e terceira quadras deste desafio, herdeiro de múltiplas vozes que atravessam a memória colectiva; quadras que se inserem, enquanto unidades independentes, reaproveitadas, na dinâmica cultural que as gerou:

- Canta daí, rapariga,

Que o teu cantar m'alegra;

Se não fosse o teu cantar,

Não vinhas aqui a esta terra.

- E louvado seja Deus,

Eu já ouvi uma voz;

Onde havia estar metida?

Dentro da casca da noz.

- Ó minha fala brandinha,

Vê lá bem no que te metes;

Não me deixes ficar mal,

Em terras que não conheces.

O receptor torna-se assim emissor, funções que, no domínio da poesia oral, alternam constantemente. O ouvinte acumula, portanto, vários papéis: o de receptor e, ao tornar-se emissor, o de co-autor. Entre o intérprete e a audiência gera-se uma reciprocidade de relações, como já vimos: pelo seu entusiasmo maior ou menor, o receptor influencia a actuação do intérprete, funcionando como incentivo ou obstáculo à prestação pública. O público, que espera do intérprete um certo discurso, uma linguagem cujas regras conhece, interfere de modo decisivo na produção da obra durante a performance: faz a apreciação da actuação, aceitando ou recusando as inovações individuais, integradas ou não no acordo cultural em que emissores e receptores se movimentam.

A rigidez da forma, como se sabe, por razões que enfoques comparatistas sobre a problemática das culturas situadas podem ajudar a descortinar, varia de cultura para cultura ou, a um nível mais subtil, dentro do mesmo sistema cultural, de autor para autor, mas o problema permanece essencialmente o mesmo: a acomodação do pensamento a um padrão rítmico, o que não torna o desafio uma arte menor.

\footnotetext{
${ }^{22}$ Cf. Nagler (1974).
} 
Nele verifica-se o contrário, porquanto o suporte formal fixo ou relativamente constante viabiliza a variação poética e temática. Inúmeros cantadores não podem recorrer a um texto modelo escrito, fixo, que lhes sirva de guia. O padrão memorizado, interiorizado, contudo, é suficiente. Por outro lado, na actuação existe o factor tempo: a composição é contínua, ininterrupta, rápida. Alguns cantadores ao desafio são peritos em acumular, combinar e reajustar fórmulas ${ }^{23}$ (pessoais ou colectivas) e temas, processo que coadjuva e enriquece a sua actuação. Preserva-se assim a tradição literária oral, através da recriação, da reactualização, de reajustamentos da matéria-prima tradicional. Uma estrutura formulística como essa, de largo emprego pela sua utilidade, pode ser integrada em qualquer desafio:

Ó desafio, desafio,

Nunca me desafiei

Outra componente característica prende-se com a saudação preambular do adversário e dos assistentes, a qual, não sendo obrigatória, é muito recorrente, encontrando-se cristalizada em fórmulas protocolares bem conhecidas dos cantadores e ouvintes. O verso introdutório "Deus te cubra de benção", para citarmos apenas um exemplo, que figura num desafio verídico que recolhemos e noutros que ouvimos mas não pudemos registar, faz também parte dum desafio (imaginado) de Abílio Costa ${ }^{24}$. Veja-se esta quadra introdutória, entre outras semelhantes que poderíamos apresentar:

E o dever do cantadore,

$\mathrm{Ai}$, quando chega ao arraiale,

$\mathrm{Ai}$, progunta a todos senhores,

Se passaram bem ou male.

No desfecho, retoma-se essa cortesia, que convive às vezes com pedidos de transigência para o recurso ao palavrão ("E as asneiras que eu disse/façam favor de desculpar"). Donde, geralmente, uma conclusão apoteótica, de expansividade estético-ideológica, com a aclamação dos participantes em ambiente de harmonias e de identidades antropológicas, simbólicas e ideológicas. Nessa fase do desafio, com efeito, resolvem-se não poucas vezes as tensões acumuladas durante a sua progressão, ou revela-se a poética do fingimento que lhe presidiu.

Num meio mental e social ultramediatizado em permanente mutação, as cantigas ao desafio encontram amplo espaço de manobra na acção de grupos amadores revivalistas e nos concursos de cantadores ao desafio que não raramente integram os programas de romarias, feiras francas e festivais de folclore, regidos por um misto de orgulho identitário e fonte minuciosamente calculada de atracção turística (como toda a poesia oral, a cantiga ao desafio não é uma prática de consumismo, mesmo se hoje beneficia muito naturalmente dos meios de comunicação de massa. Dela não se pode dizer que necessite das promoções calculadas por publicidades engenhosas). É nesses eventos construtores de memória colectiva que certamente residirá o reduto e a identidade dessa prática cultural na sociedade moderna ${ }^{25}$, com consequências já bem visíveis no aumento do número de cantadores. Em certas áreas de Espanha, mais do que até agora em Portugal, essa arte adaptou-se natural e solidamente à modernidade, através de encontros que têm lugar em grandes espaços como campos de futebol ${ }^{26}$, procurados por um público muito copioso, entusiasta e socialmente diversificado. De temáticas variadas - públicas, privadas, históricosociais, religiosas, políticas, etc. -, esses espectáculos, advindos de uma tradição evolutiva, funcionam como uma espécie de catarse ou de psicanálise colectiva. Os colectores de literatura oral participam nesse processo enquanto produtores culturais que reenviam para a comunidade textos que de outra forma não ultrapassariam a efemeridade que lhes é conatural. O que ilustra bem a producente convivência entre o oral e o escrito, registos afinal mais complementares do que mutuamente exclusivos, e a importância crescente da ultramediatização televisiva, electrónica e digital, com a fixação em registos áudio e audiovisuais. Os CDs, que transformam a oralidade primária em secundária, eternizando-a, são o sinal mais evidente da persistência de um fenómeno da cultura oral portuguesa que parece vocacionado para recusar a fossilização que muitos já lhe vaticinavam há longas décadas atrás. Prova inequívoca, ainda, de que as essencialidades culturais de uma matriz antropológica, respeitando as progressivas variantes locais, regionais e nacionais, permanecem intactas ao longo do curso histórico.

\footnotetext{
${ }^{23}$ Cf. Nogueira (1997, p. 70-87), em Literatura oral em verso. A poesia em Baião, cap. I, "Variantes": o verso "Eu não dou parte de fraco", por exemplo, muito comum no Minho, salienta a pertinácia do cantador que quer prosseguir o duelo poético, mau grado a supremacia do interlocutor.

${ }^{24}$ Cf. Nogueira (1997, p. 6), em “Abílio Costa, poeta popular”, in O comércio de Baião, com apresentação de alguns poemas.

${ }^{25}$ Pense-se, a título de exemplo, nos Encontros de Improviso, Museu de Etnologia (Lisboa), em 26 de novembro de 1994.

${ }^{26}$ Cf. Barandiaran (2000, p. 1425-1431), comunicação apresentada no VI Congreso "Cultura Europea”, ocorrido em Navarra, Espanha, entre 25 e 28 de outubro de 2000.
} 
A repetição destes produtos poéticos, em suporte escrito, áudio ou audiovisual, pode interessar ao antropólogo, ao etnógrafo ou a outro investigador, pode seduzir ou divertir, pode até promover a vedetarização de um ou outro cantador ao desafio, mas terá perdido a sua natureza única enquanto expressão superior da arte da fala comunal: a comunhão dos poetas com um auditório que os entende, os apoia, os admira ou os critica, apesar de os objectos produzidos quase sempre desaparecerem irreversivelmente à medida que são concretizados. Desse esbatimento decorre, aliás, grande parte do valor da cantiga ao desafio, território no qual estudiosos de diversas áreas do conhecimento poderão encontrar fundamentos muito significativos para alentadas investigações sobre os mistérios da mente humana: a sugestão, a força da criação poética in loco, a consequente presença indelével na memória de palavras modeladas artisticamente; palavras que são, afinal, instrumentos estético-vivenciais, utilitários, moralizadores, distractivos, jocosos, preventivos, coesivos ou subversivos, na linha do costume jogralesco peninsular. Mau grado essa precariedade, se registada por escrito, essa poesia torna-se reflexo de uma "vocalidade" (Paul Zumthor) dinâmica que as letras aparentemente mortas não ocultam por completo, dada a energia pulsional dos textos (marcada de resto nos muitos índices de oralidade patentes à superfície da versão escrita). E com uma tal estabilização há mesmo um ganho: o desafio é hoje também um produto de fruição e estesia em privado (mesmo para um único indivíduo, como já podia ser com a modalidade de cordel).

Qualquer teoria da cantiga ao desafio deve por conseguinte atender ao plano individual, equacionando o fenómeno como acto criativo pessoal, quer ao plano comunitário, como processo sociocultural de transvase entre a voz e a escrita, a precariedade e a sugestividade da palavra dita e a permanência material do cordel e, hoje, da cassete de vídeo e de áudio e do CD. A interdisciplinaridade multivectorial do enfoque evidencia a complexidade de uma especificidade poético-musical que não se esgota em componentes técnico-literárias e musicais. Exercício lúdico-inventivo com muito de antropológico e sociológico, poesia em acção, o desafio concretiza-se como macropoema dialógico constituído por dois poemas orais individuais que se cruzam numa alternância de forças, tensões e distensões variáveis. A dimensão textual é a materialidade mais visível de uma orgânica que obedece a leis de improvisação em que participam elementos linguístico-literários (arte poética, gramática, retórica, estilística, temas e remas), mas também factores extratextuais com os quais os contendores interagem de forma muito estreita (a audiência e o aparato tecnológico que envolve algumas actuações, com vista à sua mediatização).

Enquanto forma de produção simbólica, o desafio é pois uma forma privilegiada de comprometimento dos cantadores na prática da vida social; cantadores que, no seu papel de agentes estratégicos $^{27}$, ao reflectirem e discutirem paradigmas segundo os quais o grupo se deve reger, ao contarem histórias, casos, sucessos faustos ou infaustos, estão a conferir coesão cognitiva e emocional à vivência colectiva e pessoal, edificando a identidade comunal e individual. A densidade interna e profunda da cantiga ao desafio é de substância antropológica, funcionando como importante apoio do relacionamento entre o mundo (o social, o sagrado, o familiar) e o indivíduo, na sua formação e movimentação nesse espaço (onde tudo é uma surpresa e um risco). Se recordarmos que a identidade étnico-cultural é um importante factor de coesão e regulação do tecido social, mais sentido fará verberar que, já entrados no século XXI, a pervivência de culturas, paridades e géneros locais poderá transformarse numa aportação de conteúdos valiosos para a prosperidade da aldeia global e do ambiente globalizador em que nos movemos.

\section{BIBLIOGRAFIA}

ALMEIDA, Miguel Vale de. Da taberna ao café: a casa dos homens. Tradições, Lisboa, Pomo, p. 176181, s.d.

\footnotetext{
${ }^{27}$ Em Aspectos do cancioneiro popular açoriano, Pavão Júnior (1981) recorda que os serviços de afamados improvisadores eram por vezes solicitados para peditórios organizados com o objectivo de reunir fundos destinados a obras de alcance público, como a reparação de igrejas paroquiais. Estes "poetas-jograis", que encontravam ambientes e cenários propícios à demonstração da sua verve nas Festas do Senhor Santo Cristo e nas Festas do Espírito Santo, especializavam-se na palavra repentina, na revelação do grotesco social, na sátira cirúrgica dirigida às pequenas e grandes mi sérias humanas. É o que carreia a contundência explosiva desta quadra, citada pelo mesmo Pavão Júnior, da autoria de Carvalho "Talaia", um dos mais celebrados cantadores açorianos do seu tempo; quadra desferida contra a avareza inabalável de um indivíduo: "Má porta, mau passador,/ó ferrolho que não corres./Desgraçado ferrador,/tu pensas que nunca morres?" (PAVÃO JÚNIOR, 1981, p. 123).
} 
BANDEIRA, Manuel. Estrelas da tarde: poesia completa e prosa. Rio de Janeiro: Nova Aguilar, 1990.

BANDEIRA, Manuel. Poesia e prosa. Rio de Janeiro: José Aguilar, 1958. v.1.

BARANDIARAN, Asier. La cultura oral vasca en su entorno: un elemento de identidad en el marco de la globalización. In: Anais VI Congreso "Cultura Europea". Centro de Estudios Europeos - Universidad de Navarra, Espanha, 25-28 de octubre 2000, Pamplona, Cizur Menor, Thomson; Editorial Aranzadi, p. 1425-1431.

BERGSON, Henri. O riso - Ensaio sobre o significado do cómico. 2.ed. Lisboa: Guimarães Editores, 1993.

BORGES DE CASTRO. Cancioneiro popular de Mondim de Basto. Porto: Edição do Autor, 1982.

CAVIGNAC, Julie. La litterature de colportage au Nord-Est du Brésil. De l'histoire écrite au recit oral. Paris: CNRS Éditions, 1997.

COUTINHO FILHO, F. Violas e repentes - repentes populares, em prosa e verso. Pesquisas folclóricas no Nordeste Brasileiro. 2.ed. [melhorada] s. 1.: Leitura S/A; Instituto Nacional do Livro (MEC), 1972.

GUERREIRO, A. Machado. O cante a despique. Revista Lusitana - Nova Série, Lisboa, Centro de Estudos Geográficos; Instituto Nacional de Investigação Científica, n. 2, p. 61, 1981.

GUIMARÃES, Ana Paula. Nós de vozes. Acerca da tradição popular portuguesa. Lisboa: Colibri, 2000.

LISÓN, Carmelo. Perfiles simbolico-morales de la cultura gallega. Madrid: Akal, 1974.

MOURÃO, José Augusto. Poéticas da comunicação: literatura tradicional e rap. A sedução do real. Lisboa: Vega, 1998.

NAGLER, Michael. Spontaneity and Tradition: A Study in the Oral Art of Homer. Berkeley/Los Angeles: University of California Press, 1974.

NOGUEIRA, Carlos. Abílio Costa, poeta popular. O comércio de Baião, n. 116, p. 6, 26 dez. 1997.

NOGUEIRA, Carlos. Funções da poesia oral. Brigantia, Bragança, v. XIX, n. 3-4, p. 67-78, 1999.

PAVÃO JUNIOR, José de Almeida. Aspectos do cancioneiro popular açoriano. Ponta Delgada: Universidade dos Açores, 1981.

PIMENTEL, Alberto. As alegres canções do Norte. Lisboa: Dom Quixote, 1989. [ed. fac-similada] PINTO, Maria Luísa Carneiro. Por terras de Baião. Porto: Edição da Autora, 1949.

SANCHIS, Pierre. Arraial: festa de um povo. 2.ed. Lisboa: Dom Quixote, 1992.

SANTOS, Francisco Sabino dos. Entremez intitulado "O velho peralta". Lisboa: Offic. de Francisco Sabino dos Santos, 1776.

SANTOS, Idelette Muzart-Fonseca dos. La litterature de cordel au Brésil. Mémoire des voix, grenier d'histoires. Paris: L'Harmattan, 1997.

SARAIVA, Arnaldo. Assim se fazem as cousas (populares) ou os grandes desafios de um pequeno desafio. Rurália, Arouca, n. 2, p. 35-39, 1992.

SARAIVA, Arnaldo. Bacoco é Bacoco seus Bacocos. Porto: Lello \& Irmão Editores, 1995.

SARAIVA, Arnaldo. Cantigas ao desafio. Jornal de Notícias, 26/10/85.

SARAIVA, Arnaldo. Os graffiti - A propósito de "O guardador de retretes". Literatura Marginal/izada. Porto: Árvore, 1980.

SHUSTERMAN, Richard. L'art à l'état vif - La pensée pragmatiste et l'esthetique populaire. Paris: Minuit, 1982.

SOLER, Luis. As raízes árabes na tradição poético-musical do sertão nordestino. Recife: Editora Universitária/UFPE, 1978.

VASCONCELOS, José Leite de. Cancioneiro popular português. Coimbra: Por Ordem da Universidade, 1975. v.1. [Coord. e introd. de Maria Arminda Zaluar Nunes]

VASCONCELOS, José Leite de. Poesia amorosa do povo português. Lisboa: Viúva Bertrand \& Cia; Sucessores Carvalho \& Cia, 1890.

YAGUELLO, Marina. Alice no país da linguagem - Para compreender a linguística. Lisboa: Estampa, 1990.

ZERO, João. Novas cantorias para serem cantadas ao desafio entre Manuel e Maria. 15.ed. Porto:

propriedade do Bazar Feniano, Diamantino da Silva Cardoso, s.d. 